\title{
Deus é humilde e sabe dançar! Por uma teopo(ética) trinitária: a razão sensível trinitária como outra racionalidade teológica no horizonte pós-moderno
}

\author{
Orientadora: Maria Clara Lucchetti Bingemer \\ Doutorando: Rodrigo Cardoso Condeixa da Costa \\ Área de Concentração: Teologia Sistemático-Pastoral \\ Linha de Pesquisa: Religião e Modernidade
}

A tese doutoral que tens sob seus olhos nasceu de uma (pre)ocupação em relação ao conhecimento de Deus: a gnosiologia teológica. Uma pergunta tem me acompanhado (e inquietado) desde meus primeiros passos no mundo intrigante da teologia: posto que Deus desvelou Seu Rosto, conforme afirma a fé cristã, como se dá o conhecimento de Deus? Esta é uma questão, portanto, de caráter gnosiológico (epistemológico). Esta é a questão fundamental que tem norteado, entremeado minha incursão no universo da pesquisa acadêmica: a qual tem fustigado meu coração, me pondo a pensar. Pergunta que busco responder ao longo do texto e, assim, colaborar com o devir desse importante capítulo da teologia: a epistemologia teológica. Todavia, a gnosiologia teológica suscita, de pronto, a questão da racionalidade (inerente à teologia). Daí, como consequência, emergiu outra pergunta: qual concepção de racionalidade carece a teologia no horizonte pós-moderno? Tendo em vista que o conhecimento de Deus sempre se dá entre homens e mulheres situados, inseridos numa cultura, numa conjuntura histórica, social, política, econômica, etc. E seu "espírito" próprio (Zeitgeist), que nos condiciona e limita, mas simultaneamente nos possibilita e desafia a elaborar outras concepções teológicas. Neste sentido, proponho outra racionalidade teológica a partir da constatação da crise e declínio da Razão - a civilização da Razão entrou em colapso (e seu imemorial logocentrismo), presente desde as entranhas da teologia. Sendo assim, garimpamos outras fontes de inspiração. A primeira encontrada foi a rica concepção de racionalidade presente no pensamento pós-moderno, chamada doravante de razão sensível. A segunda, e não menos importante, é oriunda do 
século XVII (o século do racionalismo cartesiano): a razão sensível (cordial) do pensador francês Blaise Pascal. Fonte na qual a mística encontra-se em primeiro plano: centrada no coração. A terceira e última fonte vem do húmus fértil da fé cristã. Neste húmus fértil somos interpelados a não perder de vista (alienados) nossa real estrutura: pó (finitude), indicando não só nossa radical transitoriedade, mas mostrando com absoluta crueza nossa errância, nossa precariedade ontológica. Daí a humildade não ser uma virtude, em última análise, mas resultado de uma mínima tomada de lucidez. Este húmus é terra fértil, no qual somos acolhidos ("espaço" no qual podemos crescer), no Espírito de Vida e Amor. Trata-se do Espírito do Pai e do Filho. Uma Comunidade de Amor humilde (kénosis) e dançarina (pericóresis). Modelo de Relação no qual o Terceiro está incluído: o Espírito. Somos seres de relação, filhos e filhas da Relação. Implicando uma intercorporeidade trinitária (que acontece a partir de outra "lógica": a do terceiro incluído). Possibilitando a tessitura de uma razão sensível trinitária. Abrindo espaço para a inclusão de dimensões antes marginalizadas no decorrer da história do pensamento ocidental (e no universo da teologia), tecendo com todos estes fios, oriundos de novelos diversos, uma teopo(ética) trinitária.

Palavras-chave: Conhecimento de Deus. Razão sensível. Profetismo. 